\title{
A Case of White-Eyed Blowout Fracture
}

\author{
Min Joon Kim ${ }^{1}$, Jae Hwan Kwon ${ }^{2}$, Jung Suk Kim ${ }^{1}$, and Tai Jung Park ${ }^{1}$ (iD \\ ${ }^{\prime}$ Department of Otorhinolaryngology-Head and Neck Surgery, Maryknoll Medical Center, Busan; and \\ ${ }^{2}$ Department of Otorhinolaryngology-Head and Neck Surgery, Kosin University College of Medicine, Busan, Korea
}

\section{White-Eyed 안와 외향 골절 1예 \\ 김민준 $^{1} \cdot$ 권재환 $^{2} \cdot$ 김정석 $^{1} \cdot$ 박태정 ${ }^{1}$ \\ 메리놀병원 이비인후과, ${ }^{1}$ 고신대학교 의과대학 이비인후과학교실 ${ }^{2}$}

Received April 3, 2018

Revised August 20,2018

Accepted August 28, 2018

Address for correspondence

Tai Jung Park, MD

Department of Otorhinolaryngology-

Head and Neck Surgery,

Maryknoll Medical Center,

121 Junggu-ro, Jung-gu,

Busan 48972, Korea

Tel $+82-51-461-2692$

Fax $+82-51-462-9419$

E-mail p791216@naver.com
The 'white-eyed' blowout fracture is an orbital injury in children that is often initially misdiagnosed as a head injury because of predominant autonomic features and lack of soft tissue signs. Delays in treatment can lead to morbidity. It has been recommended that children who present with a 'white-eyed' blowout fracture should have surgery performed within 48 hours of diagnosis, otherwise prognosis is poor. We present a 12 -year-old boy who was initially misdiagnosed with a head injury due to the minor appearance of his orbital injury and his presenting complaints of nausea and vomiting.

Korean J Otorhinolaryngol-Head Neck Surg 2019;62(8):462-4

Key Words Brain concussion · Head trauma - Orbital fractures.

\section{서 론}

안와 외향 골절은 외부의 충격으로 인해 안와 내벽 또는 하 벽에 발생하는 골절로서, 성인에서는 비교적 흔하지만 소아 의 경우에서는 해부학 및 골조직 특성으로 인해 드문 것으로 알려져 있다. ${ }^{1)}$

소아 안와 외향 골절의 경우 뚜렷한 외상의 연조직 징후가 동반되지 않지만, 골절편으로 연부조직이 감돈되어 안구 관련 증상이 나타나는 경우가 발생하게 되는데 이를 white-eyed 안와 외향 골절이라 한다. ${ }^{2)}$

이러한 white-eyed 안와 외향 골절은 적정 시간 내에 수술 적 치료를 통해 교정되지 않을 경우 부분 혹은 영구적인 복 시 및 안구운동제한 등 합병증이 남을 수 있기에 신속한 진 단 및 치료가 수반되어야 한다. ${ }^{1-3)}$

저자들은 최근 소아에서 발생한 white-eyed 안와 외향 골

This is an Open Access article distributed under the terms of the Creative Commons Attribution Non-Commercial License (https://creativecommons.org/licenses/by-nc/4.0) which permits unrestricted non-commercial use, distribution, and reproduction in any medium, provided the original work is properly cited.
절 1예를 조기에 진단하고 수술적 치료로 교정하였기에 이를 문헌 고찰과 함께 보고하는 바이다.

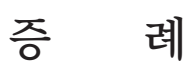

12세 남자 환아가 내원 하루 전 길에서 넘어지면서 도로 연석에 우측 안와 주위를 부딪힌 후 우안 통증 및 복시를 주 소로 본원 외래에 내원하였다. 환아는 수상 직후 두근거림과 구토를 동반한 우측 안와 주변 통증 및 복시로 인근 대학병 원 등 외상 전문의가 근무하는 종합병원 응급실 2곳에서 진 찰받았으나, 이학적 검사 및 단순 머리뼈 촬영에서 특이소견 이 관찰되지 않아 뇌진탕 진단 하에 대증치료 후 귀가 조치 되었으며 내원 직전 안과 전문 병원을 방문하여 진찰받았으 나 특별한 이상은 발견되지 않아 경과 관찰을 권유받았다고 하였다. 이학적 검사상 우측 안와 주위에 점상 출혈 및 부종 등 뚜렷한 연부조직 징후와 안구함몰은 관찰되지 않았으나, 통증을 동반한 우측 안구운동제한을 보였다. 안와 골절 유 무 판단을 위해 시행한 안면부 전산화단층촬영에서 우측 안 


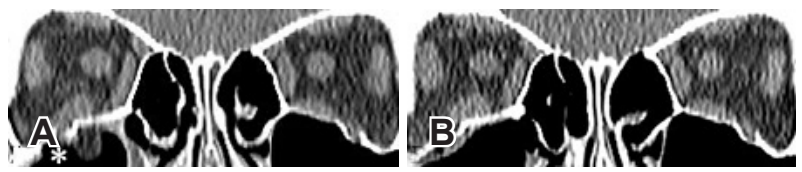

Fig. 1. Preoperative and postoperative orbital CT. Orbital CT showing suspicious finding for a right inferior orbital wall fracture with entrapment of the inferior rectus muscle (asterisk) (A). Postoperative CT presents inferior rectus muscle have been released (B).
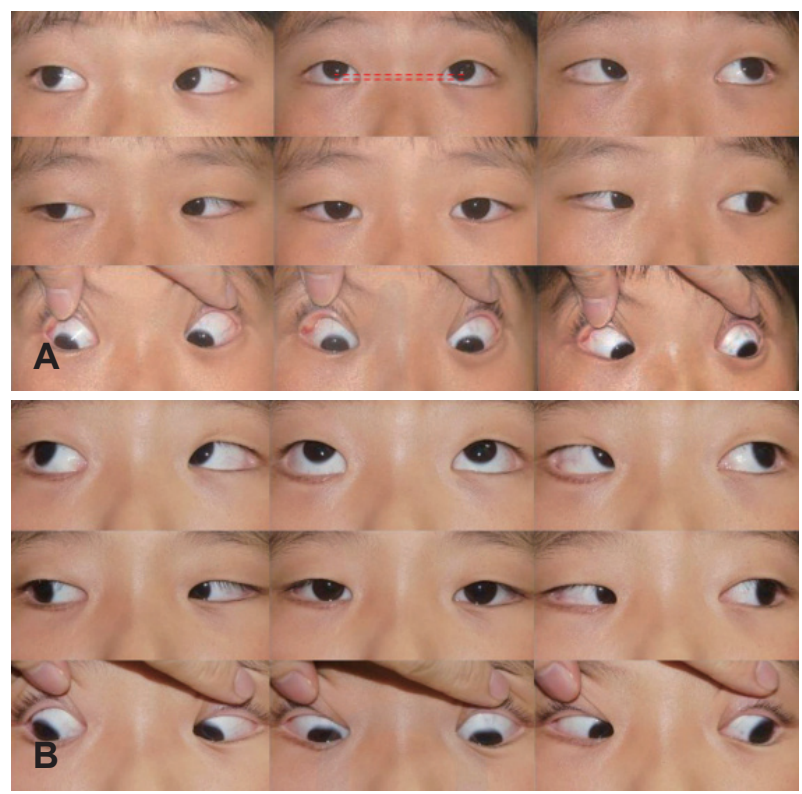

Fig. 2. Preoperative and postoperative 9 cardial positions of gaze. Extraocular eye movements demonstrating slight restriction of upgaze in the right eye with no evidence of periocular trauma (A). After operation, the patient's diplopia and eyeball movements recovered to normal range $(B)$.

와 하벽 골절 소견은 경미하였으나 골절부 주변 안구 연부조 직 일부가 골절된 파편에 감돈된 것이 의심되었다(Fig. $1 \mathrm{~A}$ ). 안과적 검사에서 좌측 하내시(inferomedial gaze)와 상방 주 시 시 우안 통증과 함께 안구운동제한과 복시를 보였으며 (Fig. 2A), 그 외 안압, 시력, 안구정렬, 대광반사 등의 검사에 서는 이상 소견이 보이지 않았다.

저자들은 수상 직후 발생한 두근거림과 구토 증상이 뇌진 탕에 의한 것이 아니라 눈심장반사에 따른 것으로 판단, 소아 에서 발생한 white-eyed 안와 외향 골절로 진단하고 지연된 정복술로 인한 영구적인 합병증이 초래될 수 있는 점을 고려 하여 응급 시험적 절개술 및 정복술을 계획하였다. 환아는 활 력징후와 심전도를 포함한 기본 술 전 검사에서 특별한 이상 을 보이지 않았다.

수상 2일째 전신마취하에 속눈썹밑절개 접근(subciliary approach)으로 안와 하벽 골절 정복술을 시행하였다. 절개 전 강제견인검사(forced duction test)를 시행하여 우측 안구의 상방 견인 시 좌측 안구에 비해 상대적인 저항이 있음을 확인 하였다.
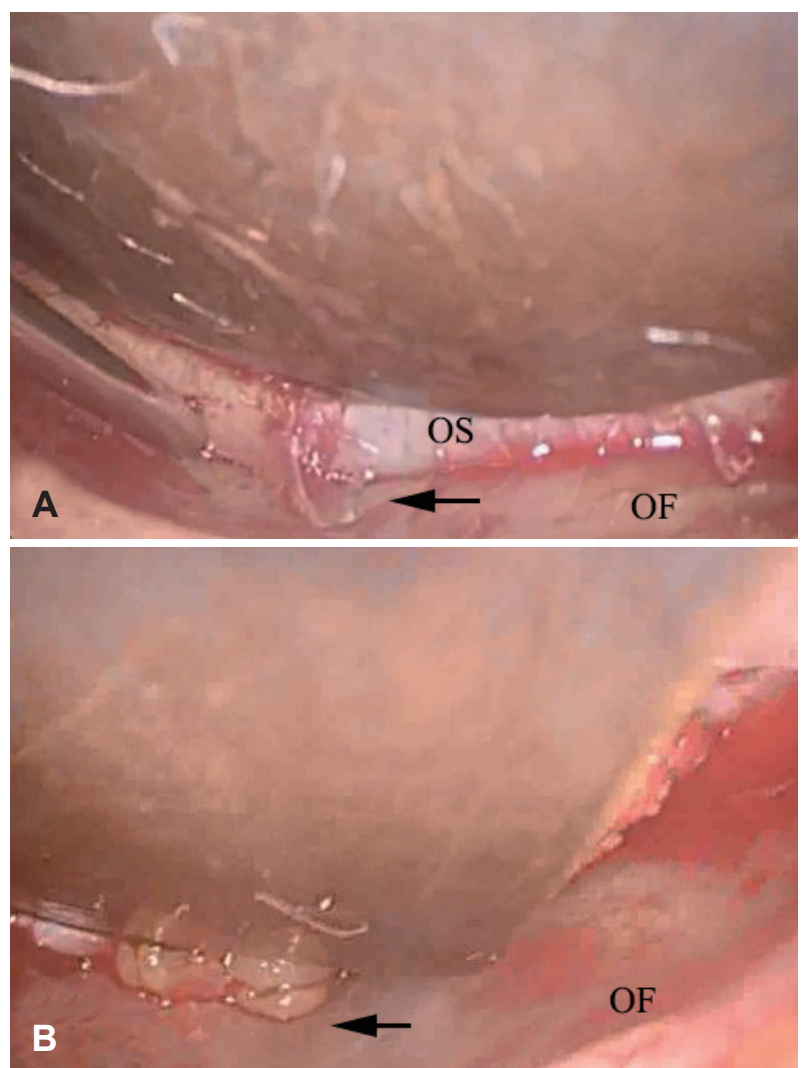

Fig. 3. Intraoperative photos. OS (A) and fat tissue (B) entrapped in fracture line of OF were remarkable at operation (arrows). OS: orbital septa, OF: orbital floor.

환측의 아랫눈썹 $2 \mathrm{~mm}$ 아래에 수평으로 피부절개를 가한 후 눈둘레근과 안와격막 사이를 박리하여 골막을 노출하였 다. 골막을 안와하연을 따라 절개 후 Freer 거상기를 이용하 여 후방으로 진행하며 안와 하벽으로부터 안와 격막을 거상 하였다. 이 과정에서 안와 하연으로부터 $1 \mathrm{~cm}$ 가량 후방에서 안와 하벽 골절선에 안와 격막과 탈출된 안와 지방이 끼여 있 음을 확인할 수 있었으며(Fig. 3), 끼여 있는 조직을 안와 하벽 으로부터 박리하였다. 이후 강제견인검사를 시행하여 기계적 인 운동제한이 사라진 것을 확인한 후, 골막과 피부를 봉합 하여 수술을 마쳤다.

안구운동제한은 수술 직후 완전히 소실되었으며 구역과 두 통 그리고 복시 역시 수술 당일 완전히 회복되었다(Fig. 2B).

술후 4일째 촬영한 안면부 전산화단층촬영에서 우측 안와 하벽 골절부에 끼였던 안구의 연부조직 일부가 잘 교정된 것 을 확인할 수 있었으며(Fig. 1B), 술 후 20개월이 지난 현재까 지 특별한 합병증 없이 경과 관찰 중이다.

\section{고 찰}

White-eyed 안와 외향 골절은 드문 외상으로 주로 18세 
이하에서 발생하며 1998년 Jordan 등리 이 안구 주위 수상 후, 안구 연부조직의 부종, 반상 출혈 등이 심하지 않으나 안구 운동 장애와 함께 통증을 호소하는 경우라고 처음 정의한 후 많은 임상 의사들에게 진단에 어려움을 주고 있다.') 이는 white-eyed 안와 외향 골절에서 안면부 전산화단층촬영은 대체로 경미한 골절 소견을 보이며 골절부가 작아 안구 조직 의 감돈이 아주 적게 보이거나 거의 보이지 않으므로 이를 발 견하기가 매우 어렵기 때문이다. ${ }^{4)}$

본 증례에서도 환아는 본원 외래 내원 전 다수의 상급종 합병원을 포함한 여러 의료 기관에서 응급의학과, 신경외과, 안과 등 여러 분야의 외상 전문 의사들에게 진료를 받았으나 white-eyed 안와 외향 골절 가능성은 제기되지 않아 진단이 늦어졌다.

White-eyed 안와 외향 골절의 진단이 늦어지는 이유 중 또 다른 하나는 눈심장반사이다. 눈심장반사는 외안근이 골절 편 사이에 끼이거나 안구 내 압력이 상승할 때 발생하는 심 장반사로서 구토와 함께 서맥을 일으키고 때론 심정지에 이 르기도 한다. 외상 진료 시 눈심장반사는 임상의에게 두개 내 손상 등 외향 골절 외 다른 부분의 이상에 주의를 기울이 게 하여 진단이 늦어지게 한다. ${ }^{5,6)}$

다수의 문헌에서 white-eyed 안와 외향 골절은 외과적 응 급 상황으로 24 48시간 이내의 응급 수술을 권장하고 있으 며, ${ }^{1,2,7)}$ 이것은 Wei와 Durairaj ${ }^{7)}$ 가 광범위한 증례를 분석하 여 보고한 종설을 통해 뒷받침되고 있다. 본 증례에서도 저자 들은 수상 후 48시간 이내에 응급 수술을 시행하여 좋은 결 과를 얻을 수 있었다. 반면에 Yang 등은 적절한 수술 술기 를 통해 감돈된 외안근이 완전히 정복된다면 24시간 이내에 수술한 환자군과 24 72시간 사이에 수술한 환자군 그리고 72시간 이후에 수술한 환자군 사이에 수술 성공률에 있어서 통계학적 차이가 없다고 보고하기도 하였다. 하지만 Kim과 $\mathrm{Kang}^{1}$ 은 white-eyed 안와 외향 골절을 수상한 후 48시간 이 내에 외과적 치료를 받은 환자군은 복시 회복에 평균 1.5 개 월 미만의 시간이 필요한 반면, 수상 후 48시간 이후에 수술 을 시행 받은 환자군은 평균 5 개월 이상의 시간이 소요되었다
고 발표한 점 등으로 미뤼, white-eyed 안와 외향 골절은 다른 안와 외향 골절보다 조기 진단 및 조기 치료가 매우 중요하다.

앞서 살펴본 증례와 같이 white-eyed 안와 외향 골절은 비 교적 전형적인 경우라 하더라도 임상적 증상과 영상의학적 소견이 명확하지 않아 경험과 식견이 부족한 임상의는 진료 시 감별진단에 포함되지 않는 경우가 많고 그로 인해 진단이 지연되기 쉬우며 때문에 수술 시기를 놓치는 경우가 빈번하 다. 따라서 소아 외상 환자를 다루는 임상의는 white-eyed 안 와 외향 골절에 대해 사전에 충분히 숙지해야 하며 의심이 될 때에는 경과 관찰을 하기보다는 충분한 설명에 의한 자발적 동의(informed consent)에 따른 시험적 절개술이 포함된 수 술을 시행하는 것이 좀 더 나은 결과를 얻을 수 있는 방법임 을 견지해야 한다.

\section{ORCID}

Tai Jung Park https://orcid.org/0000-0002-2622-0138

\section{REFERENCES}

1) Kim NH, Kang SJ. Correlation between the time to surgery and that to recovery from postoperative diplopia based on a single-center, retrospective experience: a case series of 11 patients. Arch Plast Surg 2014;41(5):486-92.

2) Jordan DR, Allen LH, White J, Harvey J, Pashby R, Esmaeli B. Intervention within days for some orbital floor fractures: the whiteeyed blowout. Ophthalmic Plast Reconstr Surg 1998;14(6):379-90.

3) Hammond D, Grew N, Khan Z. The white-eyed blowout fracture in the child: beware of distractions. J Surg Case Rep 2013;2013(7): rjt054.

4) Parbhu KC, Galler KE, Li C, Mawn LA. Underestimation of soft tissue entrapment by computed tomography in orbital floor fractures in the pediatric population. Ophthalmology 2008;115(9):1620-5.

5) Kim BB, Qaqish C, Frangos J, Caccamese JF Jr. Oculocardiac reflex induced by an orbital floor fracture: report of a case and review of the literature. J Oral Maxillofac Surg 2012;70(11):2614-9.

6) Jackson BF. Orbital trauma, bradycardia, and vomiting: trapdoor fracture and the oculocardiac reflex: a case report. Pediatr Emerg Care 2010;26(2):143-5.

7) Wei LA, Durairaj VD. Pediatric orbital floor fractures. J AAPOS 2011; 15(2):173-80.

8) Yang JW, Woo JE, An JH. Surgical outcomes of orbital trapdoor fracturein children and adolescents. J Craniomaxillofac Surg 2015; 43(4):444-7. 